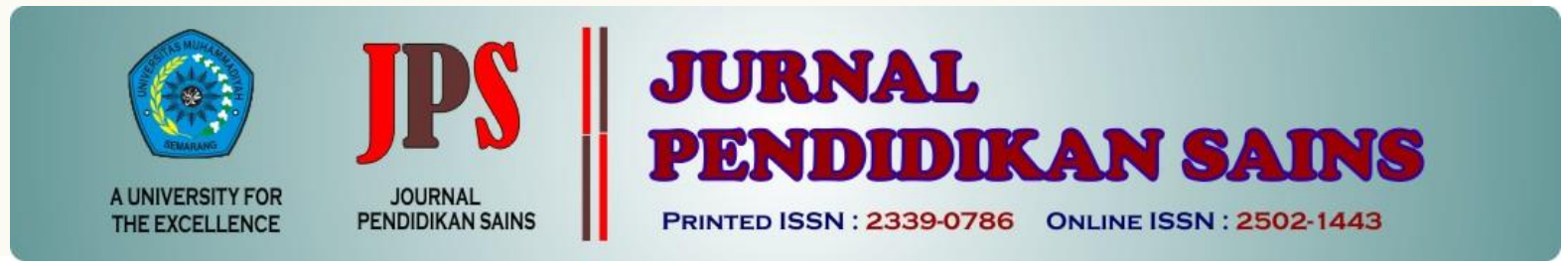

http://jurnal.unimus.ac.id/index.php/JPKIMIA

\title{
PENINGKATAN HASIL BELAJAR DAN SIKAP SOSIAL SISWA MELALUI MODEL KOOPERATIF J-TROW TERINTEGRASI PENILAIAN PEER ASSESSMENT
}

\author{
Oleh: \\ Siti Istijabatun \\ SMA Negeri 1 Pegandon Kendal
}

\begin{tabular}{ll}
\hline \multicolumn{2}{l}{ Article history } \\
\hline Submission & $: 2018-11-29$ \\
Revised & $: 2019-01-24$ \\
Accepted & $: 2019-02-14$
\end{tabular}

Keyword:

Learning Outcomes, Social Attitudes, Cooperative JTrow Models

\begin{abstract}
The average value of chemistry learning outcomes and social attitudes is still low as the background of this study, so this study aims to improve the learning outcomes and social attitudes of the students by using the J-Trow cooperative learning model integrated peer assessment of material solution. This research is a classroom action research which consisted of two cycles, with pre-cycle data taken from the students data on the previous basic competencies. The data analysis using descriptive comparative techniques by comparing data cycle I and cycle II. The results showed that there was an increasing in students' social attitudes and the number of students who achieved minimal completeness was $29.2 \%$. The student's average learning outcomes increased from 58.98 in the first cycle and 70.20 in the second cycle. Students' responses to learning showed a positive response, which is more than $50 \%$ of students give good responses.
\end{abstract}

\section{Pendahuluan}

Berdasarkan hasil wawancara dan observasi, pembelajaran kimia semester 1 pada kelas XI MIPA 2 SMA N 1 Pegandon diperoleh rata-rata nilai yang lebih rendah dari kelas yang lain, termasuk sikap sosial seperti kedisiplinan, tanggungjawab serta kerjasama antar siswa yang kurang. Guru masih mendapatkan kendala dalam upaya meningkatkan hasil belajar. Kendala tersebut disebabkan kurangnya motivasi siswa untuk belajar kimia. Kendala yang lain adalah siswa cepat lupa materi yang telah diajarkan karena kurangnya pemahaman siswa terhadap konsep yang diajarkan. Hal ini dikarenakan siswa kurang terlibat aktif dalam pembelajaran dan

*Corresponding Author:

$\begin{array}{ll}\text { Nama } & \text { : Siti Istijabatun } \\ \text { Lembaga } & \text { : SMA Negeri 1 Pegandon } \\ \text { Email } & \text { : sitiistijabatun @ gmail.com }\end{array}$

lebih cenderung menerima apa saja yang disampaikan guru. Dengan cara seperti itu siswa akan mudah merasa bosan dan kesulitan mempelajari kimia. Berdasarkan pengalaman guru dalam menerapkan salah satu tipe model pembelajaran kooperatif pada tahun sebelumnya yang hasilnya bisa meningkatkan hasil belajar siswa, maka diperlukan kembali adanya inovasi dalam model pembelajaran agar siswa lebih aktif.

Model pembelajaran yang dapat melibatkan siswa secara aktif adalah model pembelajaran kooperatif. Menurut Slavin (dalam Isjoni, 2012:12), pembelajaran kooperatif adalah suatu model pembelajaran dimana siswa belajar dan bekerja dalam kelompok-kelompok kecil secara kolaboratif 
dengan struktur kelompok heterogen. As'ari (dalam Hobri, 2009:43) menyatakan bahwa di dalam belajar kooperatif, siswa tidak hanya dituntut secara individual berupaya untuk mencapai sukses atau berusaha mengalahkan rekan mereka, melainkan dituntut dapat bekerja sama untuk mencapai hasil bersama, aspek sosial sangat menonjol dan siswa dituntut untuk bertanggung jawab terhadap keberhasilan kelompoknya.

Inovasi pembelajaran kooperatif yang dilakukan dalam penelitian ini adalah dengan memadukan berbagai tipe dalam model kooperatif. Yaitu tipe jigsaw dan tipe two stay two stray yang disingkat J-Trow kependekan dari Jigsaw, Two Stay Two Stray, Wall Gallery. Penelitian yang menggabungkan beberapa tipe ini akan menghasilkan pembelajaran yang lebih efektif dan menjadi solusi penyelesaian masalah hasil belajar dan sikap sosial yang dihadapi di kelas.

Permasalahan dalam penelitian ini adalah bagaimana model pembelajaraan kooperatif J-Trow terintegrasi penilaian peer assessment dapat meningkatkan hasil belajar dan sikap sosial siswa kelas XI MIPA 2, bagaimana hasil belajar dan sikap sosial siswa kelas XI MIPA 2 setelah menggunakan pembelajaran kooperatif $J$-Trow terintegrasi penilaian peer assessment pada materi larutan dan bagaimana respon siswa kelas XI MIPA 2 terhadap pembelajaran kooperatif J-Trow terintegrasi penilaian peer assessment pada materi larutan.

Penelitian ini bertujuan untuk mendeskripsikan pembelajaraan kooperatif $J$ Trow terintegrasi penilaian peer assessment dalam meningkatkan hasil belajar dan sikap sosial siswa kelas XI MIPA 2, mendeskripsikan hasil belajar dan sikap sosial siswa kelas XI MIPA 2 setelah menggunakan pembelajaran kooperatif $J$-Trow terintegrasi penilaian peer assessment pada materi larutan, dan mendeskripsikan respon siswa kelas XI MIPA 2 terhadap pembelajaran kooperatif $J$ Trow terintegrasi penilaian peer assessment pada materi larutan.

Pembelajaran kimia akan lebih efektif apabila didukung oleh tersedianya bahan ajar yang sesuai dengan kebutuhan siswa dan metode serta model pembelajaran yang mengaktifkan siswa. Penguasaan guru dalam metode atau model pembelajaran merupakan daya dukung dalam keberhasilan pembelajaran. Model yang digunakan dalam penelitian ini adalah pengembangan dari model pembelajaran kooperatif. Adapun sintak model pembelajaran kooperatif (Suprijono, 2012:5) disajikan dalam tabel berikut.

Tabel 1. Sintak Model Pembelajaran Kooperatif FASE - FASE PERILAKU GURU

Fase 1 : present goals Menjelaskan tujuan and set pembelajaran dan Menyampaikan mempersiapkan tujuan dan memper peserta didik siap siapkan peserta didik belajar.

\begin{tabular}{|c|c|}
\hline $\begin{array}{l}\text { Fase } 2 \text { : present } \\
\text { information } \\
\text { Menyajikan } \\
\text { informasi }\end{array}$ & $\begin{array}{l}\text { Mempresentasikan } \\
\text { informasi kepada } \\
\text { paserta didik secara } \\
\text { verbal. }\end{array}$ \\
\hline $\begin{array}{l}\text { Fase } 3 \text { : organize } \\
\text { students into learning } \\
\text { teams } \\
\text { Mengorganisir } \\
\text { peserta didik ke } \\
\text { dalam tim - tim } \\
\text { belajar }\end{array}$ & $\begin{array}{l}\text { Memberikan } \\
\text { penjelasan kepada } \\
\text { peserta didik tentang } \\
\text { tata cara pembentukan } \\
\text { tim belajar dan } \\
\text { membantu kelompok } \\
\text { melakukan transisi } \\
\text { yang efisien. }\end{array}$ \\
\hline $\begin{array}{l}\text { Fase } 4 \text { : assist team } \\
\text { work and study } \\
\text { Membantu kerja tim } \\
\text { dan belajar }\end{array}$ & $\begin{array}{l}\text { Membantu tim- tim } \\
\text { belajar selama peserta } \\
\text { didik mengerjakan } \\
\text { tugasnya. }\end{array}$ \\
\hline $\begin{array}{l}\text { Fase } 5 \text { : test on the } \\
\text { materials } \\
\text { Mengevaluasi }\end{array}$ & $\begin{array}{l}\text { Menguji pengetahuan } \\
\text { peserta didik } \\
\text { mengenai berbagai } \\
\text { materi pembelajaran } \\
\text { atau kelompok- } \\
\text { kelompok } \\
\text { mempresentasikan } \\
\text { hasil kerjanya. }\end{array}$ \\
\hline $\begin{array}{l}\text { Fase } 6 \text { : provide } \\
\text { recognition } \\
\text { Memberikan } \\
\text { pengakuan atau } \\
\text { penghargaan }\end{array}$ & $\begin{array}{l}\text { Mempersiapkan cara } \\
\text { untuk mengakui usaha } \\
\text { dan prestasi individu } \\
\text { maupun kelompok. }\end{array}$ \\
\hline
\end{tabular}

Beberapa hasil penelitian sebelumnya terkait dengan pembelajaran kooperatif menyatakan bahwa penerapan model pembelajaran kooperatif dengan strategi rotating trio exchange dapat meningkatkan hasil belajar siswa (Dina dkk, 2014:50). Dari penghitungan nilai akhir siswa, diperoleh data mengenai ketuntasan belajar siswa. Ketuntasan belajar siswa mengalami peningkatan, yaitu $71,79 \%$ pada siklus I 
menjadi $87,18 \%$ pada siklus II. Sementara Suparman, dkk (2014:293) dalam penelitiannya menyimpulkan bahwa penerapan model pembelajaran kooperatif tipe jigsaw pada materi pencemaran lingkungan dapat meningkatkan aktivitas dan hasil belajar siswa kelas VII SMPN I Sahu tahun pelajaran 2013/2014 pada materi pencemaran lingkungan. Sejalan dengan itu, Naibaho (2014:59) juga menyimpulkan hal yang sama dalam penelitiannya tentang model pembelajaran kooperatif tipe Jigsaw yang dapat meningkatkan hasil belajar siswa kelas VII-2 SMP Negeri 3 Hinai.

Terkait dengan penilaian peer assessment, Sriyati (2016:375) menyatakan bahwa hasil penilaian siswa melalui pelaksanaan peer assessment pada kegiatan praktikum biologi dianggap cukup efektif dibandingkan hasil penilaian guru, karena hampir separuh penilaian siswa (44,3\%) sama dengan penilaian guru. Demikian pula dinyatakan oleh Rochmiyati (2013:333) bahwa penilaian peer assessment mempunyai dampak positif pada peningkatan perolehan nilai rata-rata kelas pada kecakapan kognitif.

\section{Metode Penelitian}

Jenis Penelitian

Penelitian ini merupakan penelitian tindakan kelas (PTK).

Waktu dan Tempat Penelitian

Penelitian tindakan kelas (PTK) ini dilakukan pada bulan Januari - Maret 2018 dengan mengambil tempat penelitian di SMA Negeri 1 Pegandon.

Subjek Penelitian

Subyek dalam penelitian ini adalah siswa kelas XI.MIPA 2 SMA Negeri 1 Pegandon dengan jumlah 41 Siswa terdiri dari 12 siswa laki-laki dan 29 siswa perempuan.

Prosedur

Penelitian tindakan kelas ini menggunakan dua siklus dengan perincian siklus I dilaksanakan empat kali pertemuan dan siklus II dilaksanakan enam kali pertemuan. Adapun prosedur penelitian ini diawali dengan tahap pra siklus. Data yang digunakan pada tahap pra siklus adalah data nilai dari siswa kelas XI.MIPA 2 kompetensi dasar sebelumnya. Pada siklus I yang dilakukan selama empat kali pertemuan diakhiri dengan pengambilan tes akhir atau post tes.

Tahapan berikutnya adalah siklus II yang dilakukan selama enam kali pertemuan. Pada siklus II ini disediakan waktu lebih banyak daripada siklus I karena materi yang dibahas oleh kelompok ahli lebih banyak dan lebih luas cakupannya. Pelaksanaan diskusi kelompok ahli diberikan waktu dua kali pertemuan, sedangkan diskusi kelompok awal (homes team) disediakan waktu tiga kali pertemuan. Untuk presentasi dalam bentuk wall gallery masih sama dengan siklus I yaitu disediakan waktu satu kali pertemuan. Siklus II diakhiri dengan pengampilan data nilai atau post tes.

Data, Intrumen, dan Teknik Pengumpulan Data

Teknik pengumpulan data yang digunakan dalam penelitian ini adalah teknik dokumentasi, angket, observasi, dan tes. Teknik dokumentasi digunakan untuk memperoleh data nilai yang telah ada sebelumnya. Angket digunakan untuk mengetahui respon siswa terhadap pembelajaran dengan model kooperatif J-Trow yang diisi oleh siswa setelah pembelajaran. Data tentang sikap sosial diambil dengan observasi dan penilaian menggunakan teknik peer assessment dan juga pengamatan dari kolaborator. Data hasil belajar diperoleh dari soal tes yang dikerjakan siswa sebelum (pre test) dan sesudah pembelajaran (post test).

Instrumen pengumpulan data dalam penelitian ini berupa lembar angket respon siswa terhadap pembelajaran, lembar observasi untuk sikap sosial, dan lembar soal tes kognitif.

Tabel 1. Jenis Data, Instrumen, dan Teknik Pengumpulan Data

\begin{tabular}{|c|c|c|c|}
\hline No & Jenis & Instrumen & $\begin{array}{c}\text { Teknik } \\
\text { pengumpulan } \\
\text { data }\end{array}$ \\
\hline 1 & $\begin{array}{l}\text { Respon } \\
\text { siswa } \\
\text { terhadap } \\
\text { pembelajar } \\
\text { an }\end{array}$ & $\begin{array}{l}\text { Lembar } \\
\text { angket }\end{array}$ & $\begin{array}{l}\text { Angket respon } \\
\text { pembelajaran } \\
\text { untuk siswa }\end{array}$ \\
\hline 2 & $\begin{array}{l}\text { Sikap sosial } \\
\text { siswa }\end{array}$ & $\begin{array}{l}\text { Lembar } \\
\text { observasi }\end{array}$ & Observasi \\
\hline 3 & $\begin{array}{l}\text { Hasil } \\
\text { belajar } \\
\text { kognitif }\end{array}$ & $\begin{array}{l}\text { Butir soal } \\
\text { tes }\end{array}$ & Tes \\
\hline
\end{tabular}

Teknik Analisis Data 
a. Analisis data observasi sikap sosial

Analisis data observasi sikap sosial dilakukan dengan menggunakan analisis deskriptif komparatif, yaitu dengan membandingkan hasil perolehan nilai pada lembar observasi masing-masing siswa untuk tiap item pernyataan pada indikator sikap sosial pada siklus I dan siklus II kemudian dilanjutkan dengan menarik kesimpulan.

b. Analisis data respon siswa pada pembelajaran

Lembar angket respon siswa digunakan untuk mengukur tanggapan siswa terhadap model pembelajaran kooperatif J-Trow. Lembar angket ini terdiri dari beberapa pernyataan di mana setiap item mempunyai bobot yang sama yaitu 4 untuk pilihan sangat setuju (SS), 3 untuk pilihan setuju (S), 2 untuk pilihan kurang setuju (KS), dan 1 untuk pilihan tidak setuju (TS).

\section{c. Analisis Hasil Belajar}

Data yang diperoleh dari tes hasil belajar yang diberikan sebelum dan sesudah pembelajaran dianalisis menggunakan analisis deskriptif komparatif, yaitu dengan membandingkan hasil belajar siswa yang ditunjukkan oleh perolehan nilai post test masing-masing siswa pada siklus I dan siklus II kemudian dilanjutkan dengan menarik kesimpulan.

\section{Indikator Keberhasilan}

Indikator keberhasilan dalam penelitian ini adalah siswa yang mencapai KKM sebesar 70 meningkat jumlahnya pada siklus II dibanding pada siklus I, rata-rata hasil belajar kimia dan sikap sosial siswa pada siklus II meningkat dibanding pada siklus I dan pra siklus, serta respon siswa lebih dari $50 \%$ yang memperoleh predikat baik.

\section{Hasil Penelitian dan Pembahasan}

Hasil Penelitian

Pada kondisi prasiklus ditemukan hasil belajar siswa kelas XI.MIPA 2 yang masih rendah yaitu rata-rata yang diperoleh sebesar 52,93 dengan jumlah siswa yang belum mencapai KKM sebanyak 31 siswa dan hanya 10 siswa yang sudah tuntas. KKM pada kelas XI semester 1 tahun pelajaran 2017 / 2018 adalah 70 .
Pada tahap prasiklus sikap sosial siswa yang juga masih rendah, hal ini dapat diketahui dari pengamatan guru dimana siswa masih mencoba melihat jawaban teman yang lain saat penilaian harian, siswa yang tidak tepat waktu dalam mengumpulkan tugas, serta ada kecenderungan siswa kurang aktif saat pembelajaran dengan diskusi ataupun presentasi.

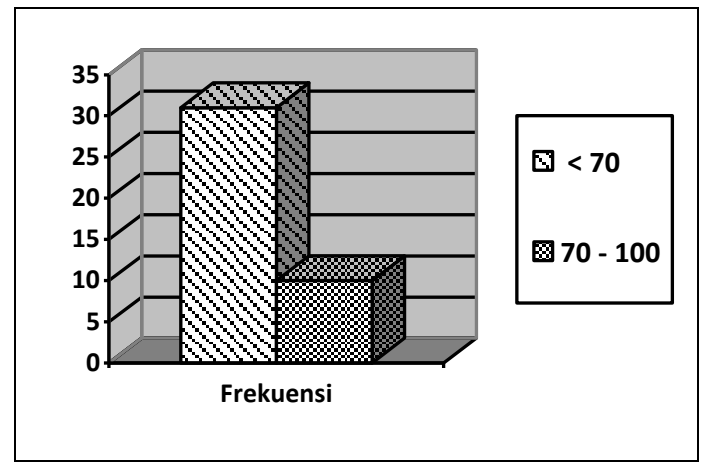

Grafik 1. Hasil Belajar Prasiklus

Tahap siklus I diakhiri dengan pengambilan data tes akhir atau post test. Dari hasil post test diperoleh rata-rata 58,98, dan dari dilakukan analisis perolehan hasil tiap kelompok.

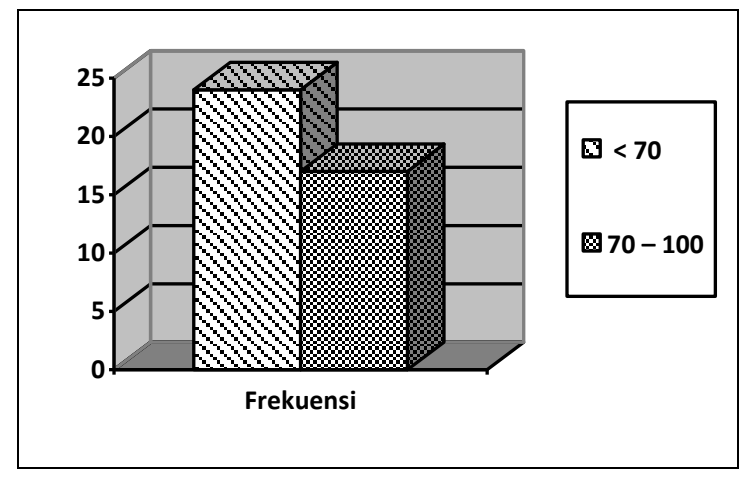

Grafik 2. Hasil Belajar Siklus I

Pada post test siklus II diperoleh ratarata hasil belajar siswa sebesar 70,20. Hasil analisis perolehan nilai siswa pada post test siklus II digunakan sebagai dasar pemberian reward untuk kelompok dengan rata-rata nilai terbaik. 


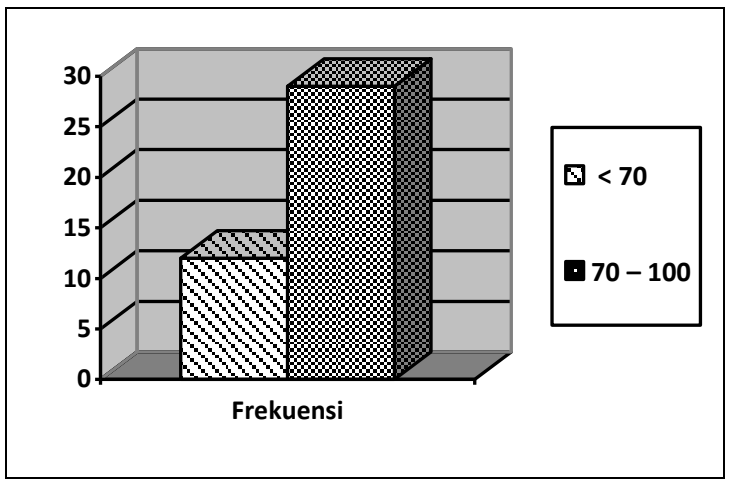

Grafik 3. Hasil Belajar Siklus II

Sikap sosial diamati pada pembelajaran siklus I dan siklus II. Rekapitulasi hasil observasi sikap sosial dari perolehan skor tertinggi (skor 4) dapat dilihat pada grafik berikut ini.

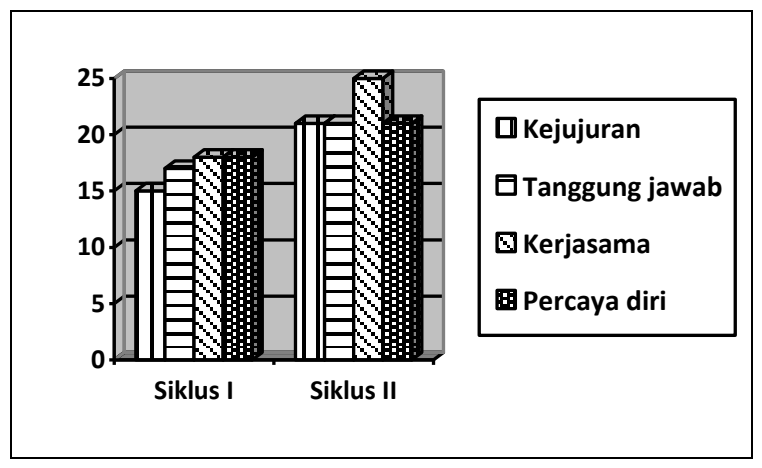

Grafik 4. Hasil Observasi Sikap Sosial

Respon siswa terhadap pembelajaran menggunakan model kooperatif J-Trow menggunakan angket diperoleh data sebagai berikut:

Tabel 2. Hasil Angket Respon Siswa

\begin{tabular}{llll}
\hline No. & Rentang Skor & Predikat & Frekuensi \\
\hline 1 & $86-100$ & Sangat & 1 \\
& & baik & \\
2 & $76-85$ & Baik & 30 \\
3 & $60-75$ & Cukup & 10 \\
\hline
\end{tabular}

Pembahasan

Sesuai dengan amanah kurikulum 2013 dimana siswa harus dipersiapkan untuk memiliki kecakapan abad 21, maka siswa harus dibiasakan berpikir tingkat tinggi dan kreatif. Inovasi model pembelajaran kooperatif yang dilakukan dalam penelitian ini adalah dengan memadukan berbagai tipe dalam model kooperatif, yaitu tipe jigsaw dan tipe two stay two stray. Kegiatan diskusi yang dilakukan dalam penelitian ini menggunakan model pembelajaran kooperatif tipe jigsaw, sedangkan kegiatan presentasi kelompok awal dilakukan dengan tipe two stay two stray dengan teknik wall gallery. Perpaduan berbagai tipe ini disingkat dengan J-Trow.

Pembelajaran dengan model kooperatif J-Trow adalah satu model pembelajaran yang dapat diterapkan. Pada pembelajarannya siswa dalam kelompok ahli dituntut untuk menganalisis materi untuk menemukan konsep dengan benar kemudian ditransfer kepada anggota kelompok yang lain dalam kelompok awal, sehingga semua anggota kelompok memiliki pemahaman yang benar. Disinilah keterampilan berpikir tingkat tinggi siswa diperlukan untuk memecahkan permasalahan yang dihadapi.

Berdasarkan pengamatan peneliti selama pembelajaran berlangsung, siswa tampak lebih enjoy, terutama saat presentasi dalam wall gallery. Siswa bebas berjalan-jalan untuk berpindah dari kelompok satu ke kelompok yang lain dan terjadi interaksi yang baik antar kelompok. Perbedaan persepsi atau pemahaman konsep tak luput juga terjadi dalam kegiatan ini, terjadi antar kelompok yang saling berkunjung, sehingga diskusi semakin seru. Adapula kelompok yang sudah menguasai konsep dengan benar dan dapat menjelaskan pertanyaan-pertanyaan yang dilontarkan anggota lain yang berkunjung di wall gallery mereka.

Kondisi seperti tersebut diatas menunjukkan aktifitas siswa yang sangat tinggi, suasana kelas memang tampak riuh tetapi tetap terjaga kondusifitasnya. Pada kegiatan ini sikap sosial masing-masing siswa juga terlatih. Bertanggung jawab atas hasil diskusi kelompoknya, bekerjasama dalam kelompok, saling menghargai pendapat kelompok lain, jujur mengakui kesalahan jika memang konsep yang mereka pahami masih belum benar, dan percaya diri untuk memaparkan hasil diskusi mereka dalam bentuk jawaban pertanyaan untuk pertanyaan yang diajukan kelompok lain.

Dalam kegiatan ini peneliti juga melakukan pengamatan pada paparan presentasi masing-masing kelompok, dengan membuat catatan-catatan yang akan digunakan untuk konfirmasi di akhir kegiatan, kemudian bersama-sama dengan siswa menarik kesimpulan. 
Berdasarkan data yang diperoleh dari nilai post test siklus I dapat dilihat bahwa terdapat 17 siswa yang mencapai nilai minimal 70 atau berkisar $41,5 \%$ siswa mencapai KKM, hal ini menunjukkan adanya peningkatan dibanding pada data pra siklus yang hanya 10 siswa yang mencapai KKM atau sekitar $24,4 \%$ siswa. Peningkatan ini belum signifikan, sehingga dilanjutkan pada siklus II agar hasilnya lebih optimal.

Tindakan refleksi pada siklus I yang dilakukan adalah memaksimalkan kerjasama siswa. Siswa yang sudah bisa memahami konsep dengan benar dalam kelompok membantu siswa yang kesulitan atau tertinggal, memberikan teguran halus untuk siswa yang tidak mau bekerja sama atau dengan cara memberitahu bahwa tidak akan mendapat reward jika kerja tim tidak maksimal. Pelaksanaan proses pembelajaran pada siklus I sudah berjalan dengan baik dan lancar, meskipun masih ada kekurangan pada saat pelaksanaan. Pada siklus I secara keseluruhan terlihat masih belum mencapai target keberhasilan yang direncanakan, sehingga perlu diadakan perbaikan pada siklus II agar dapat mencapai ketuntasan yang optimal.

Pelaksanaan siklus II dilakukan setelah dilakukan refleksi dari siklus I. Hal-hal yang ditemui pada siklus I menjadi dasar untuk melakukan tindakan pada siklus II. Pembagian materi pada siklus II menggunakan kompetensi dasar 3.11 dan 3.12. Karena cakupan materi yang dibahas lebih luas maka pada siklus II ini diberikan waktu lebih lama yaitu enam kali pertemuan. Dengan menambah pertemuan pada siklus II akan membuat siswa lebih leluasa dalam membahas materi yang menjadi tanggung jawabnya.

Pengamatan sikap sosial siswa dilakukan dengan teknik peer assessment yaitu penilaian dilakukan oleh siswa dalam satu kelompok, artinya antar siswa dalam masing-masing kelompok saling menilai satu sama lain berdasarkan instrumen observasi sikap sosial yang telah dibagikan. Teknik penilaian ini dipilih karena dapat meringankan guru untuk menilai dalam kelompok, akan tetapi siswa bisa jadi belum terbiasa dengan teknik penilaian peer assessment, maka guru perlu mempersiapkan dengan matang serta menyampaikan terlebih dahulu kepada siswa tentang rambu-rambu penilaian ini sebelum dilakukan.
Dari hasil penilaian menggunakan lembar observasi, tampak bahwa sikap sosial siswa mengalami peningkatan. Peningkatan sikap sosial ini diharapkan selanjutnya akan melekat dan menjadi karakter yang baik bagi siswa. Pembelajaran model kooperatif J-Trow mampu mendorong siswa untuk memiliki sikap sosial yang lebih baik karena kegiatannya membuat siswa bersikap jujur, yaitu menilai pendapat orang lain dengan objektif, menuliskan data dan menyampaikan sesuai dengan hasil diskusi, serta mengakui kelebihan orang lain serta mulai mengakui kekurangan yang ada pada dirinya. Pada aspek tanggung jawab tampak bahwa siswa melaksanakan tugas dengan penuh tanggung jawab dan tepat waktu, serta saling berinteraksi dan bekerja sama satu dengan yang lain. Siswa saling menghargai pendapat anggota lain dan dapat menerima kritikan maupun masukan dari anggota lain, meskipun dari hasil pengamatan masih ada siswa yang tampak masih suka memaksakan pendapatnya. Sikap percaya diri tampak pada saat menyampaikan informasi kepada anggota kelompok ataupun antar kelompok dengan tenang dan tidak mudah cemas.

Hal tersebut senada dengan kesimpulan yang disampaikan oleh Dina, dkk (2014:50), bahwa penerapan model pembelajaran kooperatif dapat menumbuhkan rasa percaya diri siswa. Demikian pula yang disampaikan Suparman, dkk (2014:293) bahwa terjadi peningkatan aktifitas siswa maupun aktivitas guru serta persepsi kuesioner siswa setelah pembelajaran dengan menggunakan model pembelajaran Kooperatif tipe Jigsaw

Hasil belajar siswa pada siklus II lebih tinggi dibanding pada siklus I. Terdapat 29 siswa yang sudah mencapai ketuntasan minimal pada siklus II. Hal ini menunjukkan bahwa pembelajaran menggunakan model kooperatif JTrow mampu meningkatkan hasil belajar siswa. Hal ini senada dengan hasil penelitian Naibaho (2014:59) bahwa model pembelajaran kooperatif tipe jigsaw dapat meningkatkan hasil belajar fisika.

Dalam hal ini peneliti melihat bahwa peningkatan hasil belajar tiap siklus hanya sedikit, yaitu dari 17 menjadi 29 siswa yang mencapai ketuntasan minimal atau peningkatannya sekitar 29,2\%, akan tetapi ratarata perolehan hasil belajar pada siklus II sudah 
memenuhi kriteria ketuntasan minimal yaitu 70,2 . Peningkatan yang belum maksimal ini menjadi bahan pemikiran lebih lanjut untuk dianalisis dan ditemukan solusi agar hasil belajar kimia lebih optimal.

Hasil rekap angket respon siswa terhadap pembelajaran model kooperatif J-Trow menunjukkan bahwa 30 siswa atau sekitar 73,2 $\%$ siswa merespon baik, bahkan ada 1 siswa merespon sangat baik. Sedangkan 10 siswa atau 24,4 \% siswa merespon cukup. Dari semua item pernyataan pada angket respon siswa, ada satu pernyataan yang sebagian siswa menjawab kurang setuju (skor 2) yaitu pada pernyataan nomor 4 (tidak menemukan kesulitan dalam pembelajaran). Sementara pada pernyataan lain sebagian besar siswa memberikan skor 3 (setuju). Data tersebut sekaligus menunjukkan bahwa sekitar $75 \%$ siswa memberikan respon positif terhadap pembelajaran model kooperatif J-Trow.

Selain lembar angket respon siswa terhadap pembelajaran, penilaian siswa terhadap pembelajaran juga diperoleh dari wawancara terhadap beberapa siswa. Hasil wawancara menunjukkan bahwa siswa merasa lebih enjoy dalam pembelajaran, diskusi terasa lebih enak dan ada tantangan untuk menyelesaikan permasalahan sendiri tanpa menggantungkan orang lain. Siswa mengharapkan model pembelajaran yang bisa mengaktifkan siswa seperti ini terus dilakukan dalam pembelajaran sehingga pembelajaran lebih bermakna.

Reward atau penghargaan diberikan kepada kelompok yang memperoleh rata-rata nilai tertinggi pada siklus I dan siklus II. Reward ini diberikan dengan tujuan memotivasi siswa agar semakin giat dalam belajar. Selain itu kelompok yang perolehan rata-rata nilainya bertahan tertinggi dari siklus I dan siklus II menunjukkan bahwa anggota kelompok tersebut bertanggung jawab atas tugasnya, saling bekerja sama dan menghargai pendapat serta mau menerima masukan dan kritikan dari anggota lain. Pada saat mempresentasikan hasil diskusi, kelompok tersebut menyampaikan dengan penuh percaya diri serta memberikan data secara objektif sesuai dengan hasil diskusi timnya. Dari hasil pengamatan, kelompok yang demikian dinilai mengalami peningkatan sikap sosial dan layak diberikan reward.

\section{Simpulan dan Saran}

Simpulan

Penerapan model pembelajaran kooperatif J-Trow terintegrasi penilaian peer assessment dilaksanakan sesuai dengan sintaks atau tahapan-tahapan pembelajaran sehingga dapat meningkatkan hasil belajar dan sikap sosial siswa kelas XI MIPA 2. Pelaksanaannya berjalan dengan lancar sesuai dengan perencanaan dan tahap pembelajaran.

Hasil belajar siswa berdasarkan data yang diperoleh dari siklus I dan siklus II juga mengalami peningkatan. Siklus I jumlah siswa yang mencapai KKM ada 17 siswa, sedangkan pada siklus II meningkat menjadi 29 siswa yang mencapai KKM. Dengan kata lain terjadi peningkatan sebesar 29,2\%. Rata-rata hasil belajar meningkat dari 58,98 pada siklus I menjadi 70,20 pada siklus II.

Sikap sosial siswa kelas XI MIPA 2 SMA N 1 Pegandon meningkat. Hal ini dapat dilihat dari pengamatan pada siklus I dan siklus II, yaitu meningkatnya jumlah siswa yang mampu menyampaikan data hasil diskusi kelompok secara objektif, mengakui kekurangan diri sendiri dan menghargai pendapat anggota lain, saling bekerja sama dan bertanggung jawab atas tugasnya serta lebih percaya diri pada saat memaparkan hasil diskusi baik dalam kelompok ataupun antar kelompok.

Respon siswa kelas XI MIPA 2 SMA N 1 Pegandon terhadap pembelajaran kooperatif J-Trow terintegrasi penilaian peer assessment pada materi larutan menunjukkan respon positif, yaitu 1 siswa memberikan respon dengan kriteria sangat baik, 30 siswa memberikan kriteria baik, sedangkan 10 siswa lainnya memberikan respon dengan kriteria cukup. Dengan kata lain lebih dari 50\% dari seluruh siswa memberikan respon baik.

\section{Saran}

Adapun saran yang penulis sampaikan dalam penelitian ini bagi guru, hendaknya melaksanakan inovasi pembelajaran, agar siswa tidak merasa bosan dan siswa juga aktif selama mengikuti pembelajaran. Model pembelajaran kooperatif J-Trow terintegrasi penilaian peer assessment dapat dijadikan sebagai alternatif pembelajaran di kelas, karena pembelajaran ini dapat meningkatkan sikap sosial dan ketuntasan hasil belajar kimia siswa. Siswa hendaknya mampu beradaptasi dan mengikuti setiap 
inovasi-inovasi dalam pembelajaran. Dalam pembentukan kelompok hendaknya memperhatikan karakteristik siswa sehingga kelompok-kelompok yang dibentuk dapat lebih komunikatif dan aktif. Bagi peneliti lainnya, diharapkan dapat mengembangkan penelitian ini guna menemukan sesuatu yang baru dan mengarah pada perbaikan serta dapat diterapkan pada materi kimia yang lain, dan pada jenjang pendidikan yang berbeda, sehingga dapat dijadikan bahan pertimbangan oleh guru bidang studi dalam menerapkannya di sekolah yang bersangkutan.

\section{Ucapan Terima Kasih}

Ucapan terima kasih penulis sampaikan kepada Ibu Umi Salamah, S.Pd. yang telah bersedia menjadi kolaborator dalam penelitian ini.

\section{Daftar Pustaka}

Bachtiar S. Bachri. (2010). Meyakinkan validitas data melalui triangulasi pada penelitian kualitatif. Jurnal teknologi pendidikan Univ Negeri Surabaya vol. 10 No. 1, April 2010 hlm. 46-62.

Bostock, S. (2004). Peer Assessment. (Online). Tersedia: http://www.iml.uts.edu.au.assessment/ student/ peer.html

Dina Frensista, dkk. 2014. Penerapan Model Pembelajaran Kooperatif. Pancaran, Vol. 3, No. 2, hal 43-52, Mei 2014

Hobri. 2009. Metodologi Penelitian Pengembangan (Development Research) (Aplikasi Pada Penelitian Pendidikan Matematika). Jember: Program Pendidikan Matematika FKIP Universitas Jember Press.

Isjoni (2012). Cooperative learning efektivitas pembelajaran kelompok. Bandung: Alfabeta

Naibaho David Ganda Tua. 2014. Penerapan Model Pembelajaran Kooperatif Tipe
Jigsaw. jurnal pendidikan fisika Vol. 3 No. 1 Juni 2014.

Pande Putu Cahya Mega Sanjiwana, dkk. 2015. Analisis Sikap Sosial Siswa. e-Journal PGSD Universitas Pendidikan Ganesha Jurusan PGSD Volume: 3 No: 1 Tahun 2015.

Rochmiyati. 2013. Model Peer Assessment pada Pembelajaran Kolaboratif Elaborasi IPS Terpadu. Jurnal Penelitian dan Evaluasi Pendidikan Nomor 2, 2013

Sriyati Siti, dkk. 2016. The Effectiveness of Peer Assessment in Assessing the Performance Ability of Students in Biology Lab Activities. Proceeding Biology Education Conference (ISSN: 2528-5742), Vol 13(1) 2016: 372-376

Suparman, dkk. (2014). Penerapan Model Pembelajaran Kooperatif tipe Jigsaw. Jurnal Bioedukasi ISSN : 2301-4678 Vol 3 No (1) September 2014.

Suprijono, Agus. 2012. Cooperative Learning : Teori dan Aplikasi PAIKEM. Yogyakarta : Pustaka Pelajar.

Sutrisno Valiant Lukad Perdana. 2016. FaktorFaktor yang Mempengaruhi Hasil Belajar Siswa. Jurnal Pendidikan Vokasi Volume 6, No 1, Februari 2016 (111-120. Online: http://journal.uny.ac.id/index.php/jpv 